\title{
Age-dependent different action of curcumin in thyroid of rat
}

\author{
Monika A. Papież, Marcin Kaja, Agata Gębarowska
}

Department of Cytobiology and Histochemistry, Pharmaceutical Faculty, School of Medicine, Jagiellonian University, Kraków, Poland

\begin{abstract}
The aging is associated with alterations in the hypothalamic-pituitary-thyroidal axis which can lead to hypothyreosis. Our previous investigations has shown that polyphenol curcumin can enhance the manifestation of hypothyreosis in rats simultanous treated with propylthiouracil. The aim of the study was to investigate the relationship between age-related changes and curcumin action in the thyroid of old rats. To this end, morphometric and radioimmunological methods were used. The study was conducted on 3- and 18-month-old male Wistar rats. The experimental rats were treated daily for 30 days by gavage with $100 \mathrm{mg} / \mathrm{kg}$ b.w. of curcumin. There were observed age-related changes in morphology and endocrine function of the thyroid. It was increase in the percentages of large follicles and significant decrease in FT3 level in 18month-old rats in comparison to 3-month ones. Curcumin treatment lead to significant increase in FT3 and FT4 levels in 3month-old experimental rats, but the level of FT3 significantly decreased in 18-month-old rats after curcumin administration. Our results show that curcumin activity depends on the functional condition of the rat thyroid which changes with age. This compound exerts stimulatory influence on the secretory function of the thyroid gland in young rats, but has rather weak antithyroid activity in old animals.
\end{abstract}

Key words: Curcumin - Thyroid - FT3 - FT4 - Aging - Histomorphometry

\section{Introduction}

The aging of an organism is connected with changes in the function of neuroendocrine systems which can lead to hypothyreosis. Thyroid diseases appear in the elderly twice as often as in the young, of which hypothyroidism afflicts $2-7 \%$ of the old population [1]. For this reason the elderly are more frequently exposed to factors triggering thyroid disorders compared to the young.

The environmental factors that are known to inhibit iodine uptake, intrathyroidal transport and organic binding include some plant components such as thiocyanate (SCN-) and cyanogenic $(\mathrm{HCN})$ glucosides. Weak antithyroid activity is shown by some polyphenols of the flavonoid group, as well as by isoflavonoids and phenolic acids [2-4]. They do not disturb thyroid functions, but act synergistically with

Correspondence: M. Papież, Dept. of Cytobiology

and Histochemistry, Pharmaceutical Faculty, CMUJ,

Medyczna 9 Str., 30-688 Kraków, Poland;

tel.: (+4812) 658-82-21, fax.: (+4812) 658-82-21,

e-mail: mfpapiez@cyf-kr.edu.pl other factors causing hypothyroidism, such as lowprotein diet or iodine deficiency. Epidemiological research revealed that polyphenols of the flavonoid group which occur in fonio millet (Digitaria exilis) are important goitrogenic factors in the endemic goiter areas of Third World countries [3,4].

Curcumin is a plant polyphenol whose yellow pigment is present in large quantities in the rhizome of turmeric (Curcuma longa) which is a component of curry powder, a spice mixture.

In vitro and in vivo studies have shown that curcumin possesses antioxidative, anti-inflammatory, cancer chemopreventive, antifungal and antiparasitic properties [5-10].

Because of its strong anti-inflammatory activity, clinical tests estimating the effectiveness of curcumin in treating Alzhaimer's disease are carried out [11]. Also its efficacy in curing colon cancer was tested [12].

Toxicological studies have shown that curcumin is characterized by low toxicity. This compound in a dose of 1 to $5 \mathrm{~g} / \mathrm{kg}$ of body weight given to rats apparently did not cause any adverse effect [13]. However, it has been reported that long-term administration of cur- 
cumin to rodents leads to hyperproliferation of thyroid epithelial cells [14].

In view of the above-mentioned facts, the present paper was designed to determine whether curcumin had influence on the secretory function and morphology of rat thyroid gland. The relationship between age and curcumin action in the thyroid gland was investigated.

The experiment was conducted on 18-month-old male Wistar rats. On the basis of literature data it is known that the level of the thyroid hormone falls down, while TSH content is not changed in old rats $[15,16]$. The biosynthetic activity of the thyroid gland was examined by measuring free thyroxine and triiodothyronine levels, as well as the colloid volume, the percentage of thyroid follicles and the height of secretory epithelium.

\section{Material and methods}

Animals. The study was conducted on inbred male Wistar rats (WAG/Krf). The animals were kept under standard conditions of $22^{\circ} \mathrm{C}$ and $50-60 \%$ humidity, on a 12 -h light-dark cycle, and were fed on a commercial pellets diet; water was provided ad libitum. The animals were divided into two age groups (3- and 18-monthold), each consisting of 12 rats ( 6 control and 6 experimental). The rats were fed daily by gavage for 30 days: control 3- (C1) and 18month-old (C2) rats - with $0.5 \mathrm{ml}$ of corn oil, experimental 3- (E1) and 18-month-old (E2) - with curcumin, $100 \mathrm{mg} / \mathrm{kg}$ b.w [17]. Their blood was collected from the tail vein, transferred to a tube with heparin as an anticoagulant to obtain plasma, and was frozen immediately at $-20^{\circ} \mathrm{C}$ until a further analysis. The animals were killed by cervical dislocation under Vetbutal anaestesia.

Histological examination of the thyroid gland. The thyroid lobes were excised and fixed in a $4 \%$ formaldehyde in the phosphate buffer $(\mathrm{pH}=7.4)$, dehydrated in a graded ethanol series and embedded in paraplast. The embedded tissues were sectioned at a thickness of $5 \mu \mathrm{m}$. Serial sections were stained with PAS and haematoxylin for a histological analysis.

Histomorphometric evaluation. To assure a random orientation of the cutting surface in all the referential areas and dimensions, a different orientation of the organs was assumed. A computer-assisted image analyzer with Multi Scan v 11.06 software was used for the assessment. The system was calibrated using a stage micrometer with a scale divided into $0.01-\mathrm{mm}$ units. The following parameters were measured: the height of the follicular epithelium, the diameter of follicles and the volume density of the colloid [18]. The follicular diameter was measured on follicles lined by squamous epithelium. The measurement was performed in both the peripheral and the central part of the lobe.

Volume density $(\mathrm{Vv})$ was assessed in 3 cross-sections from the thyroid gland of each rat. A morphometric grid and point-counting methods were used for the measurement, and hit points, i.e. places where net nodes were superimposed on the colloid, were counted. Then the volume density of that structure in the thyroid gland of individual rats was determined using the formula [18]:

$$
\mathrm{Vv}=\mathrm{Pi} / \mathrm{Pt}
$$

where: $V_{V}=$ volume density, i.e. the volume $(\mathrm{V})$ of the colloid of thyroid follicles versus the structure under study (v); $\mathrm{Pi}=$ the number of hit points $(\mathrm{P})$ in the colloid (i); $\mathrm{Pt}=$ the number of hit points (P) in all the follicles ( $\mathrm{t}$ ) of the organ under study.

The results of volume density measurement are expressed as a per cent $\left(\mathrm{V}_{\mathrm{v}} \%\right)$.
Radioimmunological analysis. Serum concentrations of FT3 and FT4 were measured by radioimmunoassay methods (Brahms Diagnostical GMBH, Germany). The level of FT3 was determined using a mouse monoclonal anti-T3 antibody labeled with ${ }^{125} \mathrm{I}$; specific activity was $<225 \mathrm{kBq}$ per vial. The concentration of FT4 was determined using an ${ }^{125} \mathrm{I}$ anti-T4 antibody; specific activity was $<150 \mathrm{kBq}$ per vial.

Statistical analysis. A one-way analysis of variance (ANOVA; $\mathrm{p}<0.05$ ) was used to determine significant differences between groups. In the absence of the homogeneity of variance, the nonparametric Kruskal-Wallis test was used.

\section{Results}

\section{Morphological analysis of the thyroid gland}

In control, 3-month-old rats, small follicles were found in the middle of the thyroid lobe, whereas mediumsize ones occurred both in the middle and at the periphery of the lobe. Large follicles were situated only peripherally. Small and medium-size follicles were lined by cuboidal or columnar epithelium, and large follicles were surrounded by cuboidal or flattened epithelium. Inside the follicles there could be seen a PAS-positive pink-stained colloid (Fig. 1A). The morphology of the thyroid gland of 3-month-old rats treated with curcumin differed from that of control animals. The follicles of these experimental rats were surrounded by higher epithelium in comparison to the corresponding control (Fig. 1B).

Large and medium-size follicles could be seen in the middle of the thyroid lobes in control 18-monthold rats, and they were surrounded by cuboidal and flattened epithelium. The follicles were filled with a less intensely stained colloid in comparison with young (3-month-old) control rats. In the thyroid of 18month-old control rats there occurred a larger quantity of the connective tissue. Leukocyte infiltration was observed in the connective tissue surrounding the follicles, as well as in the lumen of follicles in few rats (Fig. 1C). The hyperplasia of $\mathrm{C}$ cells was observed in one rat. In 18-month-old rats which were given curcumin, medium-size and small follicles were lined by columnar or cuboidal epithelium. In columnar epithelial cells there were occasionally observed large quantities of PAS-positive vacuoles. In the experimental 18-month-old rats, leukocytic deposits were rarely present in the thyroid lobes, and minor hyperplasia of the connective tissue was reported (Fig. 1D).

\section{Histomorphometric evaluation}

Thyroid follicles were divided into three classes according to their size: small (18-30 $\mu \mathrm{m}$ in diameter), medium $(31-60 \mu \mathrm{m})$ and large (above $60 \mu \mathrm{m})$. In the old control rats $(\mathrm{C} 2)$ there occurred a statistically significant increase in the quantity of large follicles compared to the 3-month-old control (C1) group (Table 1). 

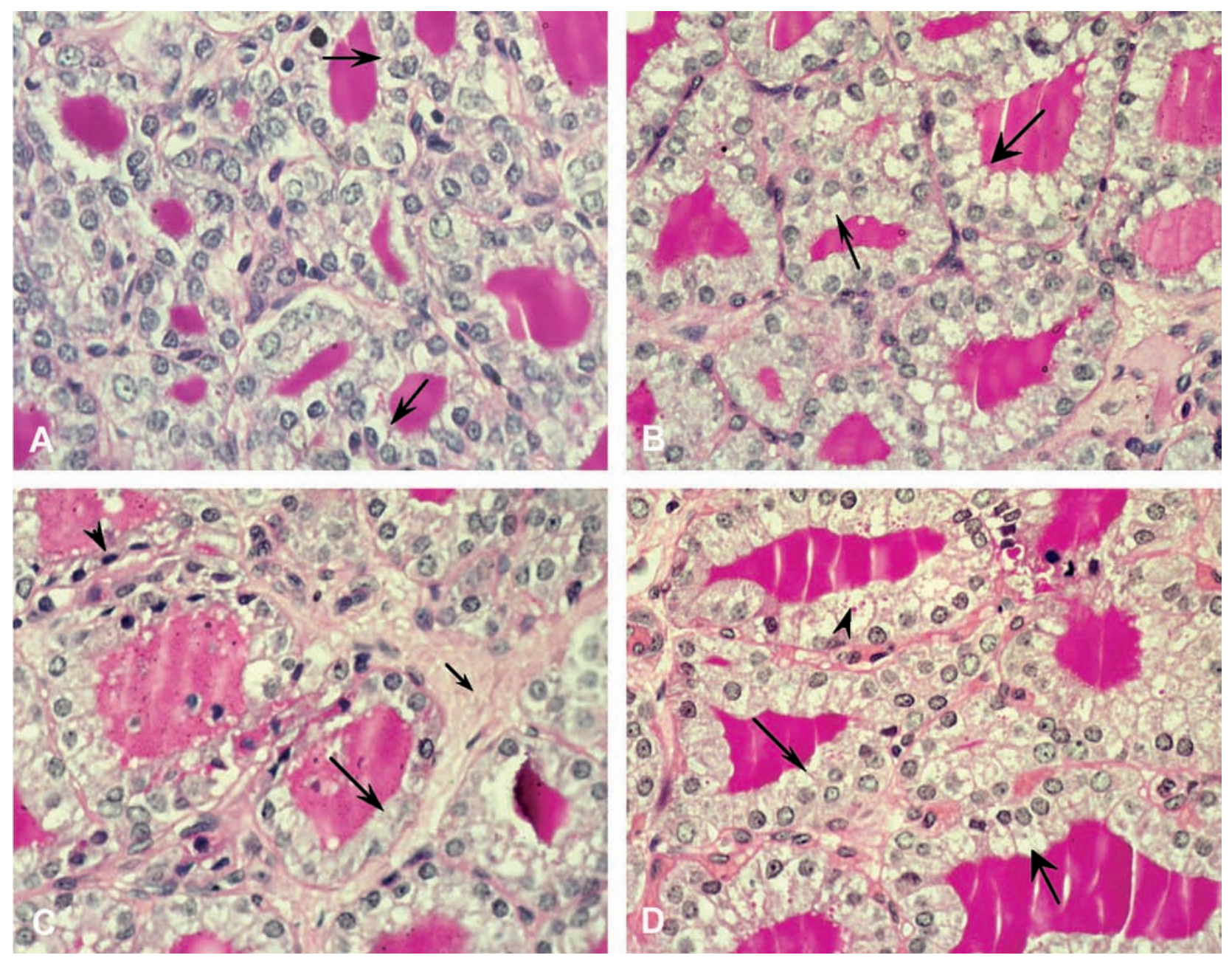

Fig. 1. Cross sections of the central part of rat thyroid glands. PAS-hematoxylin (magnification $\times 400)$. A. Small follicles are line by cuboidal epithelium (arrows) in the control 3-month-old rat. B. Follicles are surrounded by cuboidal (arrow) or columnar (large arrow) epithelium in the 3- month-old rat treated with curcumin. C. Medium-size follicles surrounded by cuboidal (arrow) and flattened (arrowhead) epithelium in control 18-month-old rat. The follicles were filled with a less intensely stained colloid in comparison with 3-monthold control rat. Small arrow shows hyperplasia of connective tissue. In the lumen of some follicles there could be seen leukocyte infiltration. D. Medium-size and small follicles are lined by cuboidal (arrow) or columnar (large arrow) epithelium in 18-month-old rat treated with curcumin. Arrowhead shows PAS-positive vacuoles.

The percentage of follicles of all classes did not significantly differ between the group of 3-month-old experimental rats (E1) and the corresponding control group (C1). In 18-month-old experimental rats (E2), no statistically significant increase in the percentage of small and medium-size follicles was observed in comparison with the $\mathrm{C} 2$ control. The epithelium of small, medium-size and large follicles was significantly higher in 18-month-old experimental rats (E2) compared to the $\mathrm{C} 2$ control (Fig. 2,3,4). There were no significant differences in epithelial height in all classes of follicles between the $\mathrm{C} 1$ and $\mathrm{E} 1$, or $\mathrm{C} 1$ and $\mathrm{C} 2$ groups. The difference in the height of follicle epithelium in all size classes between the E1 and E2 groups was statistically significant (Fig. 2,3,4).

The volume density of the colloid was not significantly changed in any group of rats (Table 1).

\section{Radioimmunological analysis}

The levels of FT3 and FT4 were significantly lower in the old control (C2) and experimental (E2) rats in comparison with respectively $\mathrm{C} 1$ or E1 groups (Fig. 5, 6). The serum levels of FT3 and FT4 were significantly increased in 3-month-old experimental rats (E1) in comparison with the $\mathrm{C} 1$ control (Fig. 5 and 6). The level of FT3 significantly fell in E2 rats compared to $\mathrm{C} 2$ ones (Fig. 5). There was no significant difference in FT4 level between E2 and C2 rats (Fig. 6).

\section{Discussion}

The influence of curcumin on thyroid function has not been well known as yet. On the one hand, some research findings reveal a slight, stimulating influence 


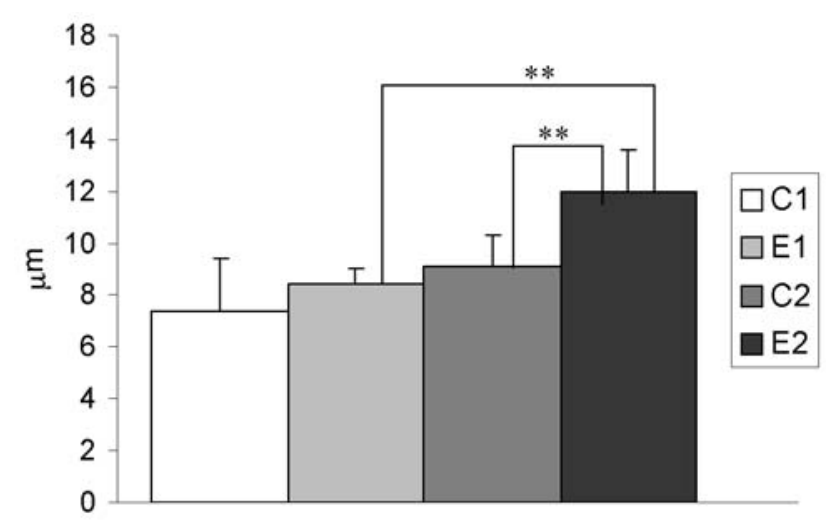

Fig. 2. The height of epithelium in small-size follicles. C1 - 3month-old, control rats. E1 - 3- month-old, curcumin treated rats. C2 - 18- month-old, control rats. E2 - 18- month-old, curcumin treated rats. Values are means $\pm \mathrm{SD}, * * \mathrm{p}<0.01$

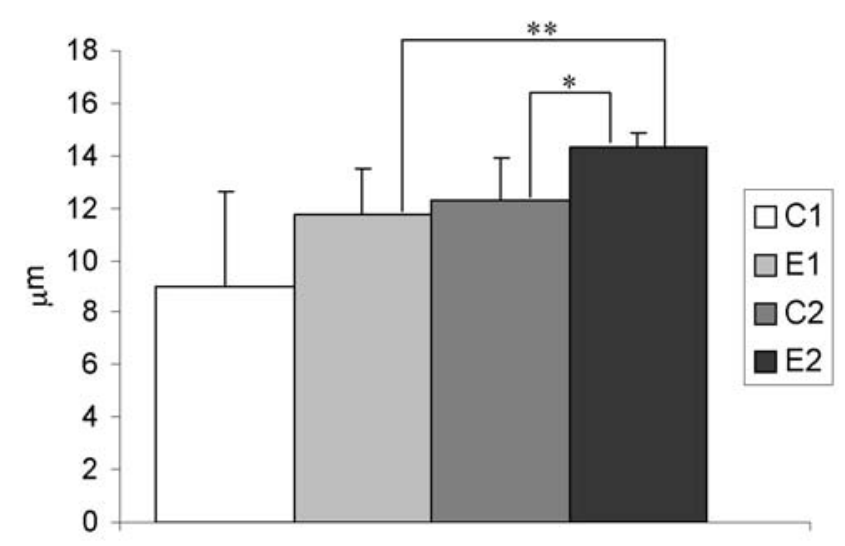

Fig. 3. The height of epithelium in medium-size follicles. C1 - 3month-old, control rats. E1 - 3- month-old, curcumin treated rats. C2 - 18- month-old, control rats. E2 - 18- month-old, curcumin treated rats. Values are means $\pm \mathrm{SD},{ }^{*} \mathrm{p}<0.05,{ }^{* *} \mathrm{p}<0.01$.

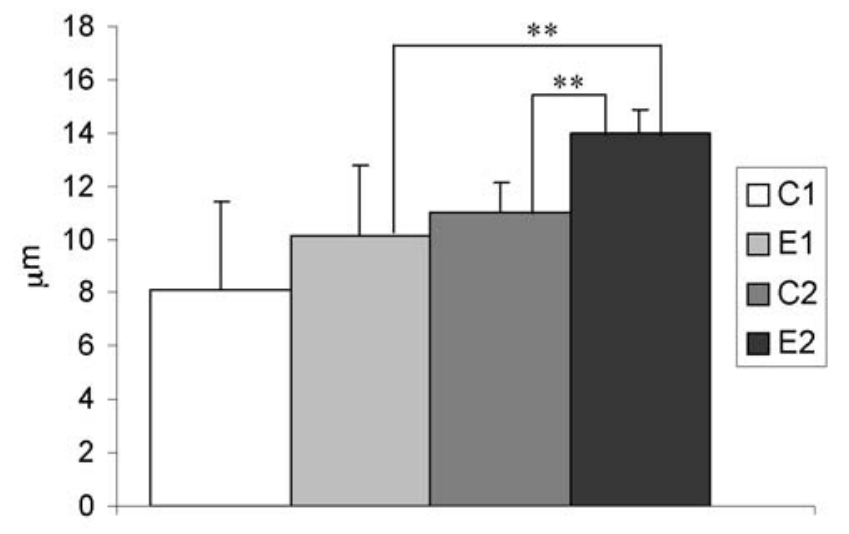

Fig. 4. The height of epithelium in largel-size follicles. C1 - 3month-old, control rats. E1 - 3- month-old, curcumin treated rats. C2 - 18- month-old, control rats. E2 - 18- month-old, curcumin treated rats. Values are means $\pm \mathrm{SD}, * * \mathrm{p}<0.01$.

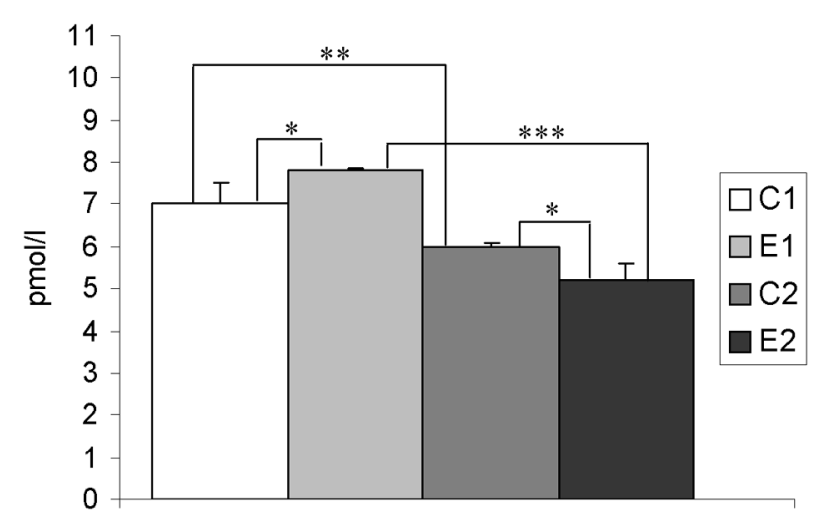

Fig. 5. The levels of FT3 in blood plasma. C1 - 3-month-old, control rats. E1 - 3- month-old, curcumin treated rats. C2 - 18- monthold, control rats. E2 - 18- month-old, curcumin treated rats. Values are means $\pm \mathrm{SD},{ }^{*} \mathrm{p}<0.05, * * \mathrm{p}<0.01, * * * \mathrm{p}<0.001$.

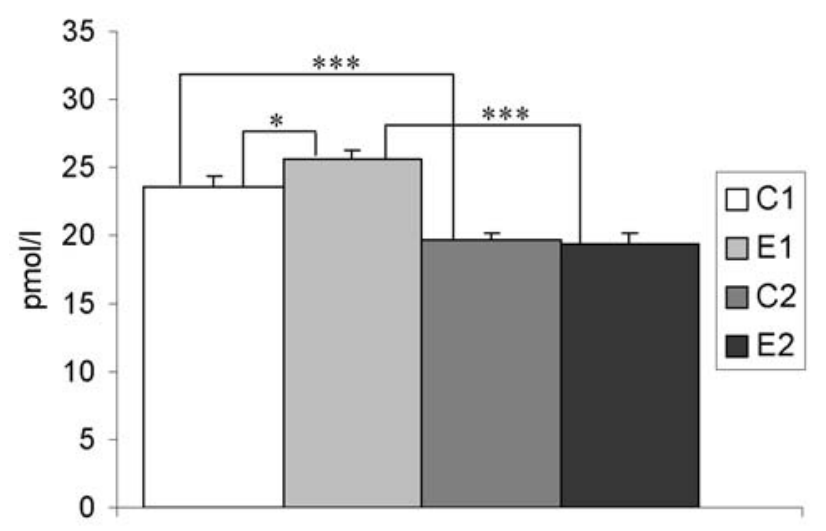

Fig. 6. The levels of FT4 in blood plasma. C1 - 3- month-old, control rats. E1 - 3- month-old, curcumin treated rats. C2 - 18- monthold, control rats. E2 - 18- month-old, curcumin treated rats. Values are means $\pm \mathrm{SD},{ }^{*} \mathrm{p}<0.05,{ }^{* *} \mathrm{p}<0.01, * * * \mathrm{p}<0.001$.

of curcumin that does not lead to hyperthyroidism in 3month-old male rats [19]. The stimulating activity of curcumin may counteract the hypothyroidism connected with ageing of the thyroid gland, whereas its antiinflammatory activity shown in a number of in vitro and in vivo studies is assumed to prevent autoaggressive diseases which more often affect the thyroid gland in elderly than in young [20-23]. On the other hand, some experiments conducted on mice have demonstrated hyperplasia of the thyroid gland after prolonged curcumin administration [14].

In the present study we focused on the relationship between the age and curcumin action in the thyroid gland of rats.

The experiment was carried out on 18-month-old rats in which the process of ageing of the thyroid gland was set in motion. At that age there could be seen intermediate changes in the morphology and secretion of 
Table 1. Volume density of the colloid and the percentage of three size-classes of the follicles. C1 - 3- month-old, control rats. E1 - 3month-old, curcumin treated rats. C2 - 18- month-old, control rats. E2 - 18- month-old, curcumin treated rats. Values are means \pm SD, ${ }^{*} \mathrm{p}<0.05$ v.s. $\mathrm{C} 1$.

\begin{tabular}{|c|c|c|c|c|}
\hline \multirow{2}{*}{ Group of rats } & \multirow{2}{*}{$\mathrm{V}_{\mathrm{v}}$ of colloid [\%] } & \multicolumn{3}{|c|}{ Follicle [\%] } \\
\cline { 3 - 5 } & & small & medium & large \\
\hline C1 & $39,75 \pm 8,21$ & $31 \pm 7,1$ & $51 \pm 1,9$ & $18 \pm 9,4$ \\
\hline E1 & $41,39 \pm 7,52$ & $34 \pm 1,2$ & $46 \pm 8,2$ & $20 \pm 7,5$ \\
\hline C2 & $45,53 \pm 5,83$ & $25 \pm 4,2$ & $48 \pm 1,1$ & $27 \pm 5,4^{*}$ \\
\hline E2 & $43,92 \pm 12,36$ & $28 \pm 1,0$ & $49 \pm 1,6$ & $23 \pm 6,3$ \\
\hline
\end{tabular}

the thyroid hormone between young (2-month-old) and old (24-month-old) rats [24].

Our own research has shown that in elderly, 18month-old rats there occur changes indicative of the ageing of the thyroid gland. FT3 and FT4 serum levels in old rats significantly fall down in comparison with young animals. These results are in line with the findings of Donda et al. [15], Cizza et al. [24] and Moreira et al. [25] who demonstrated a decrease in FT3 and FT4 serum levels in 18-month-old rats. Those authors confirmed a gradual decrease in total T3 and T4 levels with age in rats. Their study indicated that the ability of the pituitary gland to increase TSH secretion in response to the decreased level of thyroid hormones was significantly diminished in old rats.

Disturbances in the secretory function of the thyroid correlate with morphological changes in this gland. Morphological alterations, such as a lowering of the percentage of small follicles and a significant increase in the content of big ones in comparison with young rats (3-month-old) and alterations in colloid endocytosis, indicate a decrease in the biosynthetic activity of the thyroid gland in old rats. The hyperdistension of thyroid follicles with a low colloid content and numerous leukocyte infiltrations may indicate existing inflammation and progressive degenerative changes. These data are in accordance with the results obtained by Cizza et al. [24] who observed similar degenerative changes in old rats of the F344/N strain.

Our results showed that curcumin exerted a weak stimulatory influence on the biosynthetic activity of the thyroid gland in young male rats, since the levels of FT3 and FT4 significantly rose after curcumin administration, whereas alterations in the content of thyroid hormones in experimental rats did not correspond to morphological measurements compared to the control. Some literature data indicate that morphological changes do not always correlate with the secretory activity of the thyroid gland. Zaki et al. [26] reported that potassium nitrate administration had no significant influence on thyroid gland morphology despite a significant decrease in FT3 and FT4 levels in blood serum.
Despite the significant derease in the FT3 serum level, no differences in the FT4 level were observed in the old curcumin treated rats compared to the untreated control. Thus the obtained results can indicate that curcumin inhibits deiodinase activity. Some literature data show that the activity of this enzyme is reduced with age [27]. Therefore, it may be assumed that curcumin enhanced this effect. On the other hand, the unchanged FT4 content in old experimental rats compared to the control can indicate the lack of influence of the examined polyphenol on thyroperoxidase activity.

Curcumin administration to old rats led to an increase in the height of secretory epithelium and augmented the number of PAS-positive vacuoles in thyreocytes compared to the control. Similar changes were observed in the morphology of the thyroid gland in rats treated with antithyroid compounds such as bromide and propylthiouracil $[28,29]$. In the present study, these alterations in the morphology and secretory activity indicate weak inhibitory influence of curcumin on the thyroid glands of old rats.

The diminished hyperplasia in the thyroid gland of old rats after curcumin administration suggests an antiproliferative activity of curcumin. A similar inhibitory effect on the proliferation of thyreocytes was described in studies dealing with the propylthiouracil-induced hypothyroidism in rats treated with vitamin $\mathrm{E}$ [28]. It was shown that vitamin $\mathrm{E}$ attenuated the activity of protein kinase $\mathrm{C}$ (PKC) regulating the growth of cells [30]. It is proposed that curcumin also exerts antiproliferative action through $\mathrm{PKC}$, since a great number of experiments have revealed its inhibitory influence on the activity of protein kinases including PKC and the kinase of the epithelial growth factor [31]. These enzymes play a key role in signal transduction which leads to thyreocyte proliferation.

Curcumin administration to old rats reduces the number of lymphocytes infiltrating the thyroid gland. The above finding can be explained by the anti-inflammatory action of curcumin in the thyroid gland of the rats under study. A number of in vitro and in vivo experiments have revealed that curcumin reduces the 
synthesis of TNF- $\alpha$, IFN- $\gamma$, IL-1 $\beta$ and leucotriens and inhibits activation of the transcription factor NFKB which regulates the expression of many genes connected with inflammation $[32,33]$. According to Brouet \& Ohshima [34] and Zhang et al. [35], curcumin also inhibits the induction of COX-2 and iNOS. A relationship between its structure and the antiinflammatory activity has not been demonstrated as yet. It is assumed that curcumin exerts inhibitory activity on the synthesis of prostaglandines and leukotriens thanks to the presence of hydroxyl groups and phenolic rings [36].

The cause of weak curcumin action in the thyroid gland may be its low bioavailibility. This compounds is quickly metabolized to dihydroxycurcumin and tetrahydroxycurcumin in the intestine and liver [37]. It has been shown that metabolites mimic the activity of parent compounds and inhibit the expression of COX2 and prostaglandins, but their biological activity is weaker compared to curcumin [38].

Our results clearly show that curcumin exerts slight influence on thyroid function in rats, and that its activity depends on the functional condition of this gland which changes with age. It stimulates the secretory function of the thyroid gland in young rats, but has rather weak antithyroid activity in old animals.

Acknowledgements: We thank the staff of the Department of Clinical Biochemistry, University Children's Hospital of Kraków for technical support in radioimmunological analysis.

\section{References}

[ 1] Morley JE. Hormones, ageing and endocrine disorders in the eldery. In: Feling P, Frohman LA, eds. Endocrinology and Metabolism. Mc Graw-Hill, New York, 2001;1455-1482.

[2] Ferreira AC, Rosenthal D, Carvalho DP. Thyroid peroxidase inhibition by Kalanchoe brasiliensis aqueous extract. Food Chem Toxicol. 2000;38:417-421.

[3] Gaitan E. Flawonoids and the thyroid. Nutrition. 1996;12: 127-129.

[4] Sartelet H, Serghat S, Lobstein A, Ingenbleek Y, Anton R, Petitfrere E, Aguie-Aguie G, Martiny L, Haye B. Flavonoids extracted from fonio millet (Digitaria exilis) reveal potent antithyroid properties. Nutrition.1996;12: 100-106.

[5] Ammon HP, Wahl MA. Pharmacology of Curcuma longa. Planta Med. 1991;57:1-7.

[ 6] Biswas SK, McClure D, Jimenez LA, Megson IL, Rahman I. Curcumin induces glutathione biosynthesis and inhibits NFkappa B activation and interleukin- 8 release in alveolar epithelial cells: mechanism of free radical scavenging activity. Antioxid Redox Signal. 2005;7:32-41.

[7] Kalpana C, Menon V. Modulatory effects of curcumin on lipid peroxidation and antioxidant status during nicotineinduced toxicity. Pol J Pharmacol. 2004;56:581-586.

[ 8] Maheshwari RK, Singh AK, Gaddipati J, Srimal RC. Multiple biological activities of curcumin: A short review. Life Sci. 2005;78:2081-2087.

[9] Narayan S. Curcumin a multi-functional chemopreventive agent and cell-cell adhesion pathways. J Mol Histol. 2004; 35:301-307.

[10] Sharma RA, Gescher AJ, Steward WP. Curcumin: The story so far. Eur J Cancer. 2005;41:1955-1968.
[11] Yang F, Lim GP, Begum AN, Yang F, Lim GP, Begum AN, Ubeda OJ, Simmons MR, Ambegaokar SS, Chen PP, Kayed R, Glabe CG, Frautschy SA, Cole GM. Curcumin inhibits formation of amyloid beta oligomers and fibrils, binds plaques, and reduces amyloid In vivo. J Biol Chem. 2005;280:5892-5901.

[12] Johnson JJ, Mukhtar H. Curcumin for chemoprevention of colon cancer. Cancer Lett. 2007;255:170-181.

[13] Lilia HS, Hagopian M, Esber HJ, Fleischman RW, Russfield $\mathrm{AB}$, Tiedmann KM. Report on the subchronic toxicity by dosed feed of turmeric oleoresin in Fischer 344 rats and B6C3F1 mice. EGG Mason Research Institute. Report no. MRI-NTP 11-83-22. 1983. Available: http:/www.inchem.org/ documents/jecfa/jecmono/v21je06.htm.

[14] Hardisty JF, Lilja HS, Smith SL. Toxicology and carcinogenesis studies of turmeric oleoresin in $344 / \mathrm{N}$ rats and $\mathrm{B} 6 \mathrm{C} 3 \mathrm{~F} 1$ mice. Natl Toxicol Program Tech Rep Ser. 1993;427:1-275.

[15] Donda A, Reymond MJ, Lemarchand-Beraud T. Influence of age on the control of thyrotropin secretion by thyrotropinreleasing hormone in male rat. Neuroendocrinology. 1989;49: 389-394.

[16] Reymond F, Denereaz N, Lemarchand-Beraud T. Thyrotropin action is impaired in the thyroid gland of old rats. Acta Endocrinol. 1992;126:55-63.

[17] Shukla Y, Arora A, Taneja P. Antimutagenic potential of curcumin on chromosomal aberrations in Wistar rats. Mutat Res. 2002;515:197-202.

[18] Zieliński KW, Strzelecki M. Komputerowa analiza obrazu biomedycznego. Warszawa: Wydawnictwo Naukowe PWN, 2002.

[19] Papież MA, Kaja M, Nowak B. Curcumin modifies thyroid function in rats with induced hypothyroidism. Endokrynol Pol. 2005;4:566-567.

[20] Chiovato L, Mariotti S, Pinchera A. Thyroid diseases in eldery. Baillieres Clin Endocrinol Metab. 1997;11:251-270.

[21] Khopde SM, Priyadarsini KI, Venkatesan P, Rao MN. Free radical scavenging ability and antioxidant efficiency of curcumin and its substituted analogue. Biophys Chem. 1999;80:85-91.

[22] Kim HY, Park EJ, Joe EH, Jou I. Curcumin suppresses janus kinase-STAT inflammatory signaling through activation of Src homology 2 domain-containing tyrosine phosphatase 2 in brain microglia. J Immunol. 2003;171:6072-6079.

[23] Pinchera A. Thyroid autoimmunity and ageing. Hormone Res, 1995; 43: 64-68

[24] Cizza G, Brady LS, Calogero AE, Bagdy G, Lynn AB, Kling MA, Blackman MR, Chrousos GP, Gold PW. Central hypothyroidism is associated with advanced age in male fischer 344/N rats: In vivo and In vitro studies. Endocrinology. 1992;131:2672-2680.

[25] Moreira DG, Marassi MP, Correa da Costa VM, Carvalho DP, Rosenthal D. Effects of ageing and pharmacological hypothyroidism on pituitary-thyroid axis of Dutch-Miranda and Wistar rats. Exp Gerontol. 2005;40:330-334.

[26] Zaki A, Chaoui AA, Talibi A, Derouiche AF, Aboussaouira T, Zarrouck $\mathrm{K}$, Chait A, Himmi T. Impact of nitrate intake in drinking water on the thyroid gland activity in male rat. Toxicol Letters. 2004;147:27-33.

[27] Donda A \& Lemarchand-Beraud T. Ageing alters the activity of $5^{\prime}$ deiodinase in the adenohypophysis, thyroid gland and liver of male rats. Endocrinology. 1989;124:1305-1309.

[28] Öner J, Kükner A Öner H, Ozan E, Vekeler H. Effect of vitamin $\mathrm{E}$ on follicularcell proliferation and expression of apoptosis - associated factors in rat with 6-n-propyl-2-thiouracil induced goitrogenesis. Folia Histochem Cytobiol. 2003;41: 213-217.

[29] Velicky J, Titlbach M, Lojda Z, Duskova J, Vobecky M, Strbak V, Raska I. Long-term action of potassium bromide on the rat thyroid gland. Acta Histochem. 1998;100:11-23. 
[30] Omri B, Pavlovic-Hournac M. Protein kinase C activity in experimentally developed and regressed rat thyroid goiters. Mol Cell Endocrinol. 1985;40:175-180.

[31] Korutla L, Kumar R. Inhibitory effect of curcumin on epidermal growth factor receptor kinase activity in A431 cells. Biochim Biophys Acta. 1994;1224:597-600.

[32] Ammon HP, Anazodo MI, Safayhi H, Dhawan BN, Srimal RC. Curcumin: a potent inhibitor of leukotriene B4 formation in rat peritoneal polymorphonuclear neutrophils (PMNL). Planta Med. 1992;58:266.

[33] Chan MMY, Huang H, Fenton MR, Fong D. In vitro inhibition of nitric oxide synthase gene expression by curcumin, a cancer preventive natural product with anti-inflammatory properties. Biochem Pharmacol. 1998;55:1955-1962.

[34] Brouet I, Ohshima H. Curcumin, an anti-tumor promoter and anti-inflammatory agent, inhibits induction of nitric oxide synthase in activated macrophages. Biochem Biophys Res Commun. 1995;206:533-540.
[35] Zhang F, Altorki NK, Mestre JR, Subbaramaiah AK, Dannenberg AJ. Curcumin inhibits cyclooxygenase-2 transcription in bile acid- and phorbol ester-treated human gastrointestinal epithelial cells. Carcinogenesis. 1999;20:445-451.

[36] Kiuchi F, Shibuya M, Sankawa U. Inhibition of prostaglandin and leukotriene biosynthesis by gingerol and diarylheptanoids. Chem Pharm Bull. 1992;40:387-391.

[37] Ravindranath V, Chandrasekhava N. Absorption and tissue distribution of curcumin in rats. Toxicology. 1980;16:259265.

[38] Araujo CAC, Leon LL. Biological activities of Curcuma longa L. Mem Inst Oswaldo Cruz. 2001;96:723-728.

Submitted: 25 October, 2007 Accepted after reviews: 15 January, 2008 